\title{
Leptospira spp. and Toxoplasma gondii in stranded representatives of wild cetaceans in the Philippines
}

\author{
Marie Christine M. Obusan ${ }^{1,2^{*}}$ (D), Ren Mark D. Villanueva ${ }^{1,2}$, Maria Auxilia T. Siringan ${ }^{3}$, Windell L. Rivera ${ }^{1,2}$ and \\ Lemnuel V. Aragones 2,3
}

\begin{abstract}
Background: The stranding events of cetaceans in the Philippines provide opportunities for gathering biological information and specimens, especially from the pelagic forms. As part of an effort to monitor the health of wild cetaceans, this study detected Leptospira spp. and Toxoplasma gondii, causative agents of the emerging zoonotic diseases leptospirosis and toxoplasmosis respectively, in their stranded representatives. From October 2016-August 2018, 40 cetaceans (representing 14 species) that stranded nationwide were sampled for brain, cardiac muscle, skeletal muscle, kidney, and blood tissues, urine, and sera. These were subjected to molecular, serological, culture, and histopathological analyses to detect the target pathogens.
\end{abstract}

Results: T. gondii was detected in 20 (71\%) of the 28 cetaceans with biological samples subjected to either molecular detection through $R E$ gene amplification or lgG antibodies detection through agglutination-based serological assay. On the other hand, Leptospira was detected in 18 (64\%) of 28 cetaceans with biological samples subjected to bacterial culture, molecular detection through 165 rDNA amplification, or IgM antibodies detection through ELISA-based serological assay.

Conclusions: There is the plausibility of toxoplasmosis and leptospirosis in cetacean populations found in the Philippines, however, acute or chronic phases of infections in sampled stranded individuals cannot be confirmed in the absence of supporting pathological observations and corroborating detection tests. Further studies should look for more evidences of pathogenicity, and explore the specific mechanisms by which pelagic cetacean species become infected by Leptospira spp. and T. gondii. As there is growing evidence on the role of cetaceans as sentinels of land-sea movement of emerging pathogens and the diseases they cause, any opportunity, such as their stranding events, should be maximized to investigate the health of their populations. Moreover, the role of leptospirosis or toxoplasmosis in these stranding events must be considered.

Keywords: Leptospira spp., Toxoplasma gondii, Cetaceans, Stranding events, Philippines

\section{Background}

The waters of the Philippine archipelago harbor a diverse array of marine mammals. To date, 30 marine mammal species, including 28 cetaceans, the dugong (Dugong dugon) and the Asian clawless otter (Aonyx cinereus), have been confirmed in the Philippines [1].

\footnotetext{
* Correspondence: mmobusan@up.edu.ph

${ }^{1}$ Institute of Biology, College of Science, University of the Philippines,

Diliman, Quezon City 1101, Philippines

${ }^{2}$ Natural Sciences Research Institute, College of Science, University of the

Philippines, Diliman, Quezon City 1101, Philippines

Full list of author information is available at the end of the article
}

Based on limited surveys, opportunistic sightings, and stranding events, most of these species range from very rare to common in the Philippines [2]; and regarded as data deficient, endangered, threatened, and vulnerable to extinction, globally. In general, marine mammals live long, grow slowly, and have low fecundity. These features make them not only prone to over-exploitation and exposed to anthropogenic impacts but also good sentinel species $[3,4]-$ i.e. indicators of oceans and human health. The utility of these species as sentinels for ocean and human health stems from their physiological

(c) The Author(s). 2019 Open Access This article is distributed under the terms of the Creative Commons Attribution 4.0 International License (http://creativecommons.org/licenses/by/4.0/), which permits unrestricted use, distribution, and reproduction in any medium, provided you give appropriate credit to the original author(s) and the source, provide a link to the Creative Commons license, and indicate if changes were made. The Creative Commons Public Domain Dedication waiver (http://creativecommons.org/publicdomain/zero/1.0/) applies to the data made available in this article, unless otherwise stated. 
similarity with humans and their ability to "sample" or concentrate toxins and pathogens from their habitats [5]. Thus, based on the types of diseases and pathogens found in their wild populations, they can indicate human health risks posed by common water resource use [6-9]. Knowledge of their diseases and pathogens is valuable to understand the impacts of subclinical or overt diseases in their populations, routes of infection in marine ecosystems, and risks to other marine and terrestrial vertebrates [10]. This information is needed to prevent the transmission of zoonotic diseases especially at the human-wildlife interface.

One of these zoonotic diseases is leptospirosis, endemic in most tropical and subtropical regions. Southeast Asia is reported as one of its most significant foci regions, and Philippines (with 4.8 annual incidence per million) is 26th among the 28 countries with highest incidence of the disease in humans [11]. The disease is caused by pathogenic spirochetes of the genus Leptospira and is propagated in nature through chronic renal infection of carrier animals [12]. Rodents, pigs, dogs, and cattle serve as Leptospira reservoirs but different wild and domestic mammals act as accidental hosts for various serotypes of this pathogen [13-15]. Antibodies against Leptospira serovars were also detected in reptiles such as snakes, lizards, and turtles [16]. Although it is well documented and characterized in terrestrial species including humans, less information is available regarding its distribution and impact in marine mammals [17]. Previous studies reported the prevalence of leptospirosis or seropositivity to Leptospira spp. in the sirenian Peruvian Amazon manatees (Trichechus inunguis) [18] as well as in pinnipeds including harbor seals (Phoca vitulina) [19, 20], Northern elephant seals (Mirounga angustirostris) [21], California sea lions (Zalophus californianus) [22-26, 17], and Chilean South American sea lions (Otaria byronia) [27]. Most recently, two serovars Pomona and Calicola - of Leptospira interrogans were detected in serum samples of endangered Caspian seals (Pusa caspica) in the Caspian Sea off Northern Iran [28]. Information on the prevalence of Leptospira in cetaceans is scarce, with the first isolation of the proposed L. brihuegai sp. nov from Southern Right Whale (Eubalaena australis) that stranded in Argentina reported by Loffler et al. (2015) [29]. Bik et al., (2016) also reported detecting several bacteria with Leptospira sequence types in apparently healthy bottlenose dolphins (Tursiops truncatus) in California, although none of these sequence types were close to that of pathogenic L. interrogans [30].

Another zoonotic disease, toxoplasmosis, is caused by Toxoplasma gondii, a coccidian parasite of mammals with cats as definitive host [31]. Previous knowledge considers $T$. gondii as a land-based parasite, until the importance of its transmission by water [32] was implicated by waterborne outbreaks [33] and reports of infections or prevalence in marine mammals including cetaceans [34-43], fissipeds [44, 45], pinnipeds [46-49, 21, 36], and sirenian [50]. In the Philippines, Obusan et al. (2015) reported the occurrence of $T$. gondii in cetacean species [51]. This body of evidence suggests waterborne aspects of toxoplasmosis as a zoonotic disease as well as the utility of marine mammals to serve as surrogates for studying its emergence in the marine environment [36].

The stranding events of cetaceans in the Philippines provide opportunities for gathering biological information and specimens, especially from the pelagic forms. Based on Aragones et al., (2017), the trend in the frequency of local marine mammal stranding events in the Philippines has been increasing through the years, with a total of 713 strandings from 2005-August 2016 and an annual average of 65 events. These strandings are most likely to be responded in the so-called regional hotspots, administrative regions with highest stranding frequencies. As an archipelago, the Philippines is divided into 17 regions for administrative purposes, and Regions I, II, III, V, and VII, are the marine mammal stranding hotspots [52]. Cetacean stranding events have been associated with infection by pathogenic agents occurring during or after periods of immune suppression [53, 54]. However, proving this, as well as identifying the specific cause of a stranding event is a difficult task, as there is usually a synergy of factors that may cause an animal to strand. While the presence of pathogens (and the diseases associated with them) does not necessarily explain the causation of a stranding event, it indicates the health status of wild cetacean populations as well as the conditions of their habitats. As part of an effort to monitor the health of cetaceans found in the Philippines, this study detected Leptospira spp. and $T$. gondii in different biological samples obtained from individuals that stranded in the country from October 2016-August 2018.

\section{Results}

\section{Stranded cetaceans}

Forty (40) cetaceans that stranded in Philippine waters from October 2016 to August 2018, were sampled for biological materials (Table 1). Thirty-seven (37) of these were involved in single stranding events. Three (3) cetaceans were from mass stranding events; two of which were sampled from one event while one came from a separate event. Stranded individuals represented 14 cetacean species (Fig. 1). The majority of these individuals were alive when they stranded $(n=26) ; 21$ of them died while being responded or rehabilitated while three were released back into the wild.

Stranding events were recorded in Luzon $(n=25)$ and Mindanao $(n=15)$ Islands (Fig. 1$)$. More than half $(n=$ 21 ) of these strandings occurred in administrative 
regions included in the top five stranding hotspots: Region I $(n=9)$, Region II $(n=3)$, Region III $(n=1)$, and Region V $(n=8)$. The rest occurred in Region IV-A $(n=$ $4)$, Region X $(n=3)$, Region IX $(n=6)$, Region XI $(n=2)$, Region XII $(n=2)$, and Region XIII $(n=2)$. Most of the strandings $(n=16)$ occurred during the lull period before southwest (SW) monsoon, while only one was recorded during the lull before northeast (NE) monsoon. The rest occurred during SW monsoon $(n=13)$ and NE monsoon $(n=10)$.

The following biological samples were obtained (with $n=$ number of cetacean individuals): brain tissues $(n=$ $10)$, cardiac muscle tissues $(n=14)$, and skeletal muscle tissues (15) were used for molecular detection of $T$. gondii while kidney tissues $(n=12)$ were used for molecular detection, histopathological examination, and isolation of Leptospira spp. Bacterial isolation was also done using urine $(n=2)$ and blood samples $(n=22)$. Moreover, all blood samples were subjected to molecular detection of both target pathogens. Serum samples $(n=7)$ were used to detect $T$. gondii IgG antibodies and Leptospira IgM antibodies. The number of detection methods to which each cetacean was subjected depended on the type of biological sample/s collected considering the physical preservation and condition of the animal.

\section{T. gondii detection}

For the detection of $T$. gondii, 15 individuals (S1, S2, S3, S4, S5, S10, S11, S12, S13, S16, S18, S21, S22, S24, and S25) had tissue/s positive for the target $R E$ gene and six (S15, S24, S36, S37, S39, and S40) were seropositive for IgG antibodies against the protozoan parasite. One individual (S24) was both sero- and RE gene- positive. Another individual (S25) was RE-gene positive but sero-negative. Among 28 cetaceans with biological samples subjected to either gene-specific PCR assay or agglutination-based serological assay, $T$. gondii was detected in 20 (71\%) individuals (Table 2).

\section{Leptospira spp. detection}

Leptospira was detected in the blood samples of nine individuals (S2, S3, S4, S10, S15, S16, S19, S20, and S22) through $16 \mathrm{~S}$ rDNA amplification. This detection represents both pathogenic and non-pathogenic species of the genus as targeted by the primers used. Seven individuals (S15, S24, S25, S36, S37, S39, and S40) were sero-positive for Leptospira IgM antibodies. Two (2) were successfully sequenced from 15 putative leptospires that were isolated: isolate 4KT1.2 (from the kidney of S4) and isolate 6KT1.2 (from the kidney of S6) has 98 and $99 \%$ sequence similarity respectively to $L$. interrogans serovar Copenhageni strain FDAARGOS_203 (NCBI Accession No. CP020414). S6 exhibited leptospirosis-associated tubulointerstitial nephritis (Fig. 2), characterized by mild thickening of basement membrane capillaries and necrosis of convoluted tubular epithelium [22]. As this lesion was observed concurrent to bacterial isolation, it is likely that this cetacean individual had recent Leptospira infection. In addition, hemosiderosis was observed (Fig. 3). Both the isolates were found to tolerate different seawater concentrations (1, 3, 5, 7 and 10\%) up to 2 days of incubation when grown in EMJH Media and Korthof Media, indicating their ability to survive in the marine environment. Out of 28 cetaceans with biological samples subjected to any of the detection methods (culture, gene-specific PCR assay, or ELISA-based serological assay), $18(64 \%)$ individuals were positive for Leptospira spp. (Table 2).

\section{Discussion}

The detection of potentially pathogenic Leptospira spp. in cetaceans underscores the need to understand how this bacterial group moves through hosts and environments that are not usually identified in its cycle of transmission. Prager et al. (2013) reported the asymptomatic carriage of Leptospira in both wild and captive sea lions, giving clues on the long-term circulation of leptospirosis in their habitats [26]. Leptospirosis was also significantly associated with close proximity to dog parks as well as high dog-park density in California sea lions [62]. However, such case represents a coastal environment that directly receives land-based effluents. How species of Leptospira become transmitted to pelagic cetacean species (e.g., in this study, Fraser's dolphin (L. hosei), melon-headed whale (P. electra), and others) that stay in the open sea remains to be understood in relation to the ability of these bacterial group to remain viable in saltwater conditions. Elsewhere, reports on leptospirosis and seroprevalence to Leptospira were mostly on pinniped species and involved cases prompted by epizootics [24]. Among cetaceans, Leptospira spp. were only reported in Southern Right Whale (E. australis) in Argentina [29] and in bottlenose dolphins (T. truncatus) in California [30].

While leptospirosis in marine mammals is not yet substantially characterized, interpretations of detection methods may use as reference, the descriptions in humans and other mammals. Leptospirosis in humans has two phases: (1) acute phase, which is usually the first 7 days of illness (may end 3-7 days), when leptospires can be cultured and detected from the blood; and (2) immune phase, which can last for 4-30 days, when antibodies can be detected in the blood and leptospires can be cultured from the urine [63]. The limitations of serology include (1) lack of antibodies at the acute phase; (2) "anamnestic response" or the rise in antibody titer that is directed against a previous infecting serovar; (3) high degree of cross-reactions 
Table 1 Stranded cetaceans that were sampled from October 2016-August 2018

\begin{tabular}{|c|c|c|c|c|c|c|c|c|}
\hline $\begin{array}{l}\text { Strander } \\
\text { No. }\end{array}$ & Common name & Sex & Age Class & $\begin{array}{l}\text { Physical } \\
\text { Preservation } \\
\text { Code }\end{array}$ & $\begin{array}{l}\text { Type of } \\
\text { Stranding }\end{array}$ & $\begin{array}{l}\text { Date of } \\
\text { Stranding }\end{array}$ & $\begin{array}{l}\text { Season of } \\
\text { Stranding }\end{array}$ & $\begin{array}{l}\text { Region of } \\
\text { Stranding }\end{array}$ \\
\hline S1 & Grampus griseus (Risso's dolphin) & Female & Adult & 2 & Single & $\begin{array}{l}19 \text { October } \\
2016\end{array}$ & $\begin{array}{l}\text { Lull before } \\
\mathrm{NE}\end{array}$ & Region IV-A \\
\hline S2 & $\begin{array}{l}\text { Lagenodelphis hosei (Fraser's } \\
\text { dolphin) }\end{array}$ & Male & Adult & 2 & Single & $\begin{array}{l}27 \text { February } \\
2017\end{array}$ & NE & Region V \\
\hline S3 & Stenella longirostris (spinner dolphin) & Female & Adult & 2 & Single & $\begin{array}{l}\text { 04 March } \\
2017\end{array}$ & $\mathrm{NE}$ & Region V \\
\hline S4 & $\begin{array}{l}\text { Lagenodelphis hosei (Fraser's } \\
\text { dolphin) }\end{array}$ & Female & Adult & 2 & Single & $\begin{array}{l}09 \text { March } \\
2017\end{array}$ & $\mathrm{NE}$ & Region XI \\
\hline S5 & Grampus griseus (Risso's dolphin) & Unknown & Subadult & 2 & Single & $\begin{array}{l}29 \text { March } \\
2017\end{array}$ & $\mathrm{NE}$ & Region IV-A \\
\hline S6 & $\begin{array}{l}\text { Peponecaphala electra (melon- } \\
\text { headed whale) }\end{array}$ & Female & Unknown & 2 & Single & 30 April 2017 & $\begin{array}{l}\text { Lull before } \\
\text { SW }\end{array}$ & Region I \\
\hline S7 & $\begin{array}{l}\text { Feresa attenuata (pygmy killer } \\
\text { whale) }\end{array}$ & Unknown & Adult & 2 & Mass & 02 May 2017 & $\begin{array}{l}\text { Lull before } \\
\text { SW }\end{array}$ & Region V \\
\hline S8 & $\begin{array}{l}\text { Stenella attenuata (Pantropical } \\
\text { spotted dolphin) }\end{array}$ & Female & Adult & 2 & Single & $\begin{array}{l}07 \text { May 2017, } \\
\text { 0800H }\end{array}$ & $\begin{array}{l}\text { Lull before } \\
\text { SW }\end{array}$ & Region XIII \\
\hline S9 & $\begin{array}{l}\text { Stenella attenuata (Pantropical } \\
\text { spotted dolphin) }\end{array}$ & Male & Adult & 2 & Single & $\begin{array}{l}07 \text { May 2017, } \\
1400 \mathrm{H}\end{array}$ & $\begin{array}{l}\text { Lull before } \\
\text { SW }\end{array}$ & Region XIII \\
\hline S10 & Grampus griseus (Risso's dolphin) & Unknown & Adult & 2 & Single & 09 May 2017 & $\begin{array}{l}\text { Lull before } \\
\text { SW }\end{array}$ & Region V \\
\hline S11 & $\begin{array}{l}\text { Kogia breviceps (pygmy sperm } \\
\text { whale) }\end{array}$ & Male & Adult & 2 & Single & 16 May 2017 & $\begin{array}{l}\text { Lull before } \\
\text { SW }\end{array}$ & Region XI \\
\hline S12 & Grampus griseus (Risso's dolphin) & Female & Neonate & 1 & Single & 15 June 2017 & SW & Region I \\
\hline S13 & $\begin{array}{l}\text { Stenella attenuata (Pantropical } \\
\text { spotted dolphin) }\end{array}$ & Female & Subadult & 2 & Single & 21 June 2017 & SW & Region I \\
\hline S14 & Grampus griseus (Risso's dolphin) & Unknown & Adult & 2 & Single & 23 June 2017 & SW & Region III \\
\hline S15 & $\begin{array}{l}\text { Lagenodelphis hosei (Fraser's } \\
\text { dolphin) }\end{array}$ & Unknown & Unknown & 1 & Single & 02 July 2017 & SW & Region I \\
\hline S16 & $\begin{array}{l}\text { Peponocephala electra (melon- } \\
\text { headed whale) }\end{array}$ & Male & Adult & 2 & Single & 03 July 2017 & SW & Region XII \\
\hline S17 & $\begin{array}{l}\text { Stenella attenuata (Pantropical } \\
\text { spotted dolphin) }\end{array}$ & Female & Subadult & 1 & Single & 28 July 2017 & SW & Region IV-A \\
\hline S18 & Stenella longirostris (spinner dolphin) & Female & Subadult & 2 & Single & $\begin{array}{l}31 \text { August } \\
2017\end{array}$ & SW & Region XI \\
\hline S19 & Stenella longirostris (spinner dolphin) & Female & Subadult & 2 & Single & $\begin{array}{l}30 \\
\text { September } \\
2017\end{array}$ & SW & Region I \\
\hline S20 & $\begin{array}{l}\text { Kogia breviceps (pygmy sperm } \\
\text { whale) }\end{array}$ & Female & Adult & 2 & Single & $\begin{array}{l}09 \text { November } \\
2017\end{array}$ & $\mathrm{NE}$ & Region V \\
\hline S21 & $\begin{array}{l}\text { Lagenodelphis hosei (Fraser's } \\
\text { dolphin) }\end{array}$ & Female & Adult & 2 & Single & $\begin{array}{l}01 \text { December } \\
2017\end{array}$ & $\mathrm{NE}$ & Region II \\
\hline S22 & $\begin{array}{l}\text { Globicephala macrorhynchus (short- } \\
\text { finned pilot whale) }\end{array}$ & Female & Adult & 2 & Single & $\begin{array}{l}05 \text { December } \\
2017\end{array}$ & $\mathrm{NE}$ & Region I \\
\hline S23 & $\begin{array}{l}\text { Tursiops aduncus (Indo-Pacific } \\
\text { bottlenose dolphin) }\end{array}$ & Female & Adult & 1 & Single & $\begin{array}{l}15 \text { January } \\
2018\end{array}$ & $\mathrm{NE}$ & Region IX \\
\hline S24 & $\begin{array}{l}\text { Stenella attenuata (Pantropical } \\
\text { spotted dolphin) }\end{array}$ & Male & Adult & 2 & Single & $\begin{array}{l}16 \text { January } \\
2018\end{array}$ & $\mathrm{NE}$ & Region IX \\
\hline S25 & $\begin{array}{l}\text { Stenella coeruleoalba (striped } \\
\text { dolphin) }\end{array}$ & Female & Adult & 1 & Single & $\begin{array}{l}15 \text { February } \\
2018\end{array}$ & $\mathrm{NE}$ & Region V \\
\hline S26 & $\begin{array}{l}\text { Lagenodelphis hosei (Fraser's } \\
\text { dolphin) }\end{array}$ & Female & Adult & 2 & Single & 17 April 2018 & $\begin{array}{l}\text { Lull before } \\
\text { SW }\end{array}$ & Region IX \\
\hline S27 & Kogia breviceps (pygmy sperm & Male & Subadult & 2 & Single & 26 April 2018 & Lull before & Region IX \\
\hline
\end{tabular}


Table 1 Stranded cetaceans that were sampled from October 2016-August 2018 (Continued)

\begin{tabular}{|c|c|c|c|c|c|c|c|c|}
\hline $\begin{array}{l}\text { Strander } \\
\text { No. }\end{array}$ & Common name & Sex & Age Class & $\begin{array}{l}\text { Physical } \\
\text { Preservation } \\
\text { Code }\end{array}$ & $\begin{array}{l}\text { Type of } \\
\text { Stranding }\end{array}$ & $\begin{array}{l}\text { Date of } \\
\text { Stranding }\end{array}$ & $\begin{array}{l}\text { Season of } \\
\text { Stranding }\end{array}$ & $\begin{array}{l}\text { Region of } \\
\text { Stranding }\end{array}$ \\
\hline & whale) & & & & & & SW & \\
\hline $\mathbf{S} 28$ & $\begin{array}{l}\text { Kogia breviceps (pygmy sperm } \\
\text { whale) }\end{array}$ & Female & Adult & 2 & Single & 27 April 2018 & $\begin{array}{l}\text { Lull before } \\
\text { SW }\end{array}$ & Region IX \\
\hline S29 & $\begin{array}{l}\text { Balaenoptera omurai (Omura's } \\
\text { whale) }\end{array}$ & Female & Neonate & 2 & Single & 30 April 2018 & $\begin{array}{l}\text { Lull before } \\
\text { SW }\end{array}$ & Region X \\
\hline $\mathrm{S} 30$ & $\begin{array}{l}\text { Balaenoptera sp. (unidentified } \\
\text { baleen) }\end{array}$ & Unknown & Adult & 2 & Single & 03 May 2018 & $\begin{array}{l}\text { Lull before } \\
\text { SW }\end{array}$ & Region V \\
\hline S31 & $\begin{array}{l}\text { Kogia breviceps (pygmy sperm } \\
\text { whale) }\end{array}$ & Male & Adult & 2 & Single & 06 May 2018 & $\begin{array}{l}\text { Lull before } \\
\text { SW }\end{array}$ & Region IV-A \\
\hline S32 & $\begin{array}{l}\text { Kogia breviceps (pygmy sperm } \\
\text { whale) }\end{array}$ & Female & Adult & 2 & Single & 10 May 2018 & $\begin{array}{l}\text { Lull before } \\
\text { SW }\end{array}$ & Region X \\
\hline S33 & $\begin{array}{l}\text { Peponocephala electra (melon- } \\
\text { headed whale) }\end{array}$ & Female & Adult & 2 & Single & 17 May 2018 & $\begin{array}{l}\text { Lull before } \\
\text { SW }\end{array}$ & Region X \\
\hline S34 & $\begin{array}{l}\text { Stenella attenuata (Pantropical } \\
\text { spotted dolphin) }\end{array}$ & Unknown & Subadult & 2 & Single & 25 May 2018 & $\begin{array}{l}\text { Lull before } \\
\text { SW }\end{array}$ & Region I \\
\hline S35 & $\begin{array}{l}\text { Tursiops aduncus (Indo-Pacific } \\
\text { bottlenose dolphin) }\end{array}$ & Male & Adult & 2 & Single & 28 May 2018 & $\begin{array}{l}\text { Lull before } \\
\text { SW }\end{array}$ & Region IX \\
\hline S36 & $\begin{array}{l}\text { Steno bredanensis (rough-toothed } \\
\text { dolphin) }\end{array}$ & Female & Adult & 1 & Single & 02 July 2018 & SW & Region I \\
\hline S37 & Balaenoptera edeni (Bryde's whale) & Unknown & Neonate & 1 & Single & 03 July 2018 & SW & Region V \\
\hline S38 & $\begin{array}{l}\text { Stenella attenuata (Pantropical } \\
\text { spotted dolphin) }\end{array}$ & Male & Adult & 1 & Single & $\begin{array}{l}08 \text { August } \\
2018\end{array}$ & SW & Region I \\
\hline S39 & $\begin{array}{l}\text { Feresa attenuata (pygmy killer } \\
\text { whale) }\end{array}$ & Male & Adult & 1 & Mass & $\begin{array}{l}17 \text { August } \\
2018\end{array}$ & SW & Region II \\
\hline 540 & $\begin{array}{l}\text { Feresa attenuata (pygmy killer } \\
\text { whale) }\end{array}$ & Female & Adult & 1 & Mass & $\begin{array}{l}17 \text { August } \\
2018\end{array}$ & SW & Region II \\
\hline
\end{tabular}

between serogroups especially during the acute phase; and (4) differences in the sensitivity of tests, for example, earlier detection by ELISA from day 6-8 (which may cover the acute phase) compared with MAT [64]. In the case of the nine stranders (S2, S3, S4, S10, S15, S16, S19, S20, and S22) that were positive in blood PCR detection, the presence of acute infection cannot be confirmed since $16 \mathrm{~S}$ rDNA targeted both pathogenic and non-pathogenic Leptospira spp. Included in these stranders are S15 and S4, which had IgM in the blood and bacterium isolated from the kidney respectively. It is possible that a non-pathogenic Leptospira species was detected by PCR in the blood of these individuals. If this is the case, then the detected IgM in S15 was against a pathogenic serovar, or if indeed such serovar was amplified in the blood, then the IgM might have been detected early in the acute phase given the reported early detection by ELISA. As the kidney isolates from S4 and S6 were most phylogenetically related to $L$. interrogans, these cetaceans may have chronic renal carriage of leptospires (immune phase of infection) or active infection if presented with clinical symptoms such as in the case of dogs [65]. The seven stranders (S15, S24, S25, S36, S37, S39 and S40) that were sero-positive for IgM might be in the immune phase of leptospirosis. The presence of the antileptospiral IgM may be attributed to the persistence of the antibody after infection, frequent reinfection with leptospires in endemic areas, or cross-reaction with other infectious agents [66]. Overall, there is evidence for the exposure of sampled cetaceans to pathogenic Leptospira spp., but it is rather difficult to confirm the phase of infection given the limitations in the detection tests and biological samples.

It must be noted that there is $100 \%$ sero-positivity in all sera qualified for the detection of IgM antibodies against Leptospira. However, this result is limited by the fact that SERION Leptospira IgM-ELISA was only evaluated to detect the complexes formed by human IgM and Leptospira antigens representing known serovars bound to goat antihuman IgM. The test was used as an accepted surrogate to the gold standard but laborious and time-consuming Microscopic Agglutination Test (MAT) which requires the maintenance of live serovars [63]. The test's protocol claims the likelihood of cross-reactivity of goat antihuman IgM with IgM from other species [63]. While specific information on cross-reactivity of cetacean and human antibodies to Leptospira antigens are yet to be 


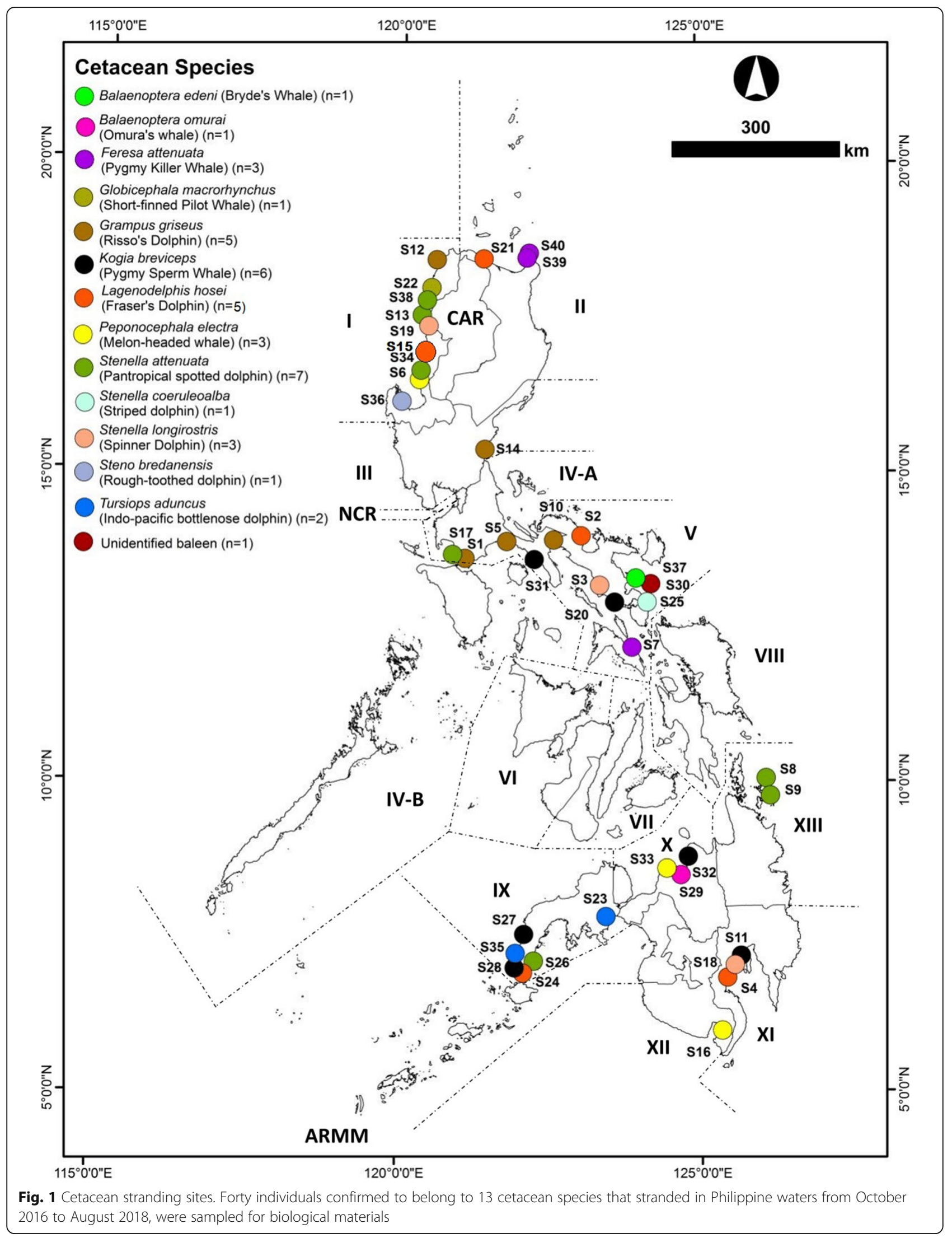


Table 2 Summary of results for detection of target pathogens

\begin{tabular}{|c|c|c|c|c|c|c|c|c|c|c|}
\hline \multirow[t]{3}{*}{$\begin{array}{l}\text { Strander } \\
\text { Code }\end{array}$} & \multirow[t]{3}{*}{ Cetacean Species (and common name) } & \multirow{2}{*}{\multicolumn{4}{|c|}{ T. gondii detection by PCR }} & \multirow[t]{3}{*}{$\begin{array}{l}\text { T. gondii } \\
\text { detection } \\
\text { by LAT }\end{array}$} & \multicolumn{2}{|c|}{$\begin{array}{l}\text { Leptospira } \\
\text { detection by } \\
\text { PCR }\end{array}$} & \multirow[t]{3}{*}{$\begin{array}{l}\text { Leptospira } \\
\text { culture }\end{array}$} & \multirow[t]{3}{*}{$\begin{array}{l}\text { Leptospira } \\
\text { detection } \\
\text { by ELISA }\end{array}$} \\
\hline & & & & & & & \multirow[t]{2}{*}{ Blood } & \multirow[t]{2}{*}{ Kidney } & & \\
\hline & & Blood & Cardiac & Skeletal & Brain & & & & & \\
\hline$\overline{S 1}$ & Grampus griseus (Risso's dolphin) & - & * & + & * & * & - & * & - & * \\
\hline S2 & Lagenodelphis hosei (Fraser's dolphin) & - & * & + & + & * & + & - & $+^{c}$ & * \\
\hline S3 & Stenella longirostris (spinner dolphin) & - & + & + & + & * & + & - & $+^{\mathrm{A}}$ & * \\
\hline S4 & Lagenodelphis hosei (Fraser's dolphin) & + & + & + & + & * & + & - & $+^{\mathrm{A}}$ & * \\
\hline S5 & Grampus griseus (Risso's dolphin) & - & + & - & * & * & - & - & * & * \\
\hline S6 & Peponecaphala electra (melon-headed whale) & * & * & * & * & * & * & * & $t^{B}$ & * \\
\hline S7 & Feresa attenuata (pygmy killer whale) & * & * & * & * & * & * & * & * & * \\
\hline 58 & Stenella attenuata (Pantropical spotted dolphin) & * & * & * & * & * & * & * & * & * \\
\hline 59 & Stenella attenuata (Pantropical spotted dolphin) & * & * & * & * & * & * & * & * & * \\
\hline S10 & Grampus griseus (Risso's dolphin) & + & + & + & + & * & + & - & - & * \\
\hline S11 & Kogia breviceps (pygmy sperm whale) & * & + & + & + & * & * & * & * & * \\
\hline S12 & Grampus griseus (Risso's dolphin) & + & * & * & * & * & - & * & - & * \\
\hline $\mathrm{S} 13$ & Stenella attenuata (Pantropical spotted dolphin) & * & + & + & * & * & * & * & $+^{B}$ & * \\
\hline S14 & Grampus griseus (Risso's dolphin) & * & - & * & * & * & * & * & $t^{\mathrm{A}}$ & * \\
\hline S15 & Lagenodelphis hosei (Fraser's dolphin) & - & * & * & * & + & + & * & - & + \\
\hline S16 & Peponocephala electra (melon-headed whale) & + & + & * & + & * & + & - & $++^{\mathrm{D}}$ & * \\
\hline S17 & Stenella attenuata (Pantropical spotted dolphin) & * & * & * & * & * & * & * & * & * \\
\hline S18 & Stenella longirostris (spinner dolphin) & + & - & + & + & * & - & - & - & * \\
\hline S19 & Stenella longirostris (spinner dolphin) & - & * & * & * & * & + & * & - & * \\
\hline S20 & Kogia breviceps (pygmy sperm whale) & - & - & * & - & * & + & - & - & * \\
\hline S21 & Lagenodelphis hosei (Fraser's dolphin) & - & + & + & * & * & - & - & $+^{\mathrm{A}}$ & * \\
\hline S22 & $\begin{array}{l}\text { Globicephala macrorhynchus (short-finned pilot } \\
\text { whale) }\end{array}$ & + & + & - & + & * & + & * & * & * \\
\hline S23 & Tursiops aduncus (Indo-Pacific bottlenose dolphin) & * & * & * & * & * & * & * & * & * \\
\hline S24 & Stenella attenuata (Pantropical spotted dolphin) & + & + & + & * & + & - & * & - & + \\
\hline S25 & Stenella coeruleoalba (Striped dolphin) & + & * & * & * & - & - & * & - & + \\
\hline S26 & Lagenodelphis hosei (Fraser's dolphin) & * & * & * & * & * & * & * & * & * \\
\hline S27 & Kogia breviceps (pygmy sperm whale) & - & - & - & * & * & - & - & - & * \\
\hline S28 & Kogia breviceps (pygmy sperm whale) & * & * & $*$ & * & * & * & * & * & * \\
\hline S29 & Balaenoptera omurai (Omura's whale) & * & * & * & * & * & * & * & * & * \\
\hline S30 & Balaenoptera sp. (unidentified baleen) & * & * & * & * & * & * & * & * & * \\
\hline S31 & Kogia breviceps (pygmy sperm whale) & - & * & - & - & * & - & - & - & * \\
\hline S32 & Kogia breviceps (pygmy sperm whale) & * & * & * & * & * & * & * & * & * \\
\hline S33 & Peponocephala electra (melon-headed whale) & - & * & * & * & * & - & * & - & * \\
\hline S34 & Stenella attenuata (Pantropical spotted dolphin) & - & * & - & * & * & - & - & - & * \\
\hline S35 & Tursiops aduncus (Indo-Pacific bottlenose dolphin) & - & * & * & * & * & - & * & - & * \\
\hline S36 & Steno bredanensis (rough-toothed dolphin) & * & * & * & * & + & * & * & * & + \\
\hline S37 & Balaenoptera edeni (Bryde's whale) & - & * & * & * & + & - & * & - & + \\
\hline S38 & Stenella attenuata (Pantropical Spotted dolphin) & * & * & * & * & $*$ & * & * & * & * \\
\hline S39 & Feresa attenuata (pygmy killer whale) & * & * & * & * & + & * & * & * & + \\
\hline S40 & Feresa attenuata (pygmy killer whale) & * & * & * & * & + & * & $*$ & * & + \\
\hline
\end{tabular}


Table 2 Summary of results for detection of target pathogens (Continued)

\begin{tabular}{|c|c|c|c|c|c|c|c|c|c|c|}
\hline \multirow[t]{3}{*}{$\begin{array}{l}\text { Strander } \\
\text { Code }\end{array}$} & \multirow[t]{3}{*}{ Cetacean Species (and common name) } & \multirow{2}{*}{\multicolumn{4}{|c|}{ T. gondii detection by PCR }} & \multirow[t]{3}{*}{$\begin{array}{l}\text { T. gondii } \\
\text { detection } \\
\text { by LAT }\end{array}$} & \multicolumn{2}{|c|}{$\begin{array}{l}\text { Leptospira } \\
\text { detection by } \\
\text { PCR }\end{array}$} & \multirow[t]{3}{*}{$\begin{array}{l}\text { Leptospira } \\
\text { culture }\end{array}$} & \multirow[t]{3}{*}{$\begin{array}{l}\text { Leptospira } \\
\text { detection } \\
\text { by ELISA }\end{array}$} \\
\hline & & & & & & & \multirow[t]{2}{*}{ Blood } & \multirow[t]{2}{*}{ Kidney } & & \\
\hline & & Blood & Cardiac & Skeletal & Brain & & & & & \\
\hline Total pos & tive results out of screened cetaceans & $8 / 22$ & $10 / 14$ & $10 / 15$ & $8 / 10$ & $6 / 7$ & $9 / 22$ & $0 / 12$ & $15 / 23$ & $7 / 7$ \\
\hline
\end{tabular}

+ positive for T. gondii or Leptospira spp.

- negative for T. gondii or Leptospira spp.

$+{ }^{A}$ one putative leptospire isolate

$+^{\mathrm{B}}$ two putative leptospire isolates

$+^{\mathrm{C}}$ three putative leptospire isolates

$+{ }^{\mathrm{D}}$ four putative leptospire isolates

*biological sample for testing not available/enough

available, it is said that humans follow the classical IgM response to Leptospira antigens similar to animals [63]. The suitability of cetaceans as sentinels for marine zoonoses such as leptospirosis may be supported by evidences of cross-reactivity of (1) antibodies to human antigens and tissues of the bottlenose dolphin (T. truncatus) [67] suggesting that the applied serological assay has a reasonable sensitivity at least for many cetacean species; (2) human and bovine antibodies in paraffin-wax embedded tissues of striped dolphin (S. coeruleoalba) [63]; and (3) commercially available terrestrial-specific antibodies (from pig, rat, mice, and humans) to dolphins, allowing the characterization of the immune cell subsets of under human care and free-ranging dolphins [63].

In the Philippines, the detection of pathogenic Leptospira spp. in coastal soil after the storm surge brought about by typhoon Haiyan that devastated the Eastern
Visayas part of the Philippines was reported by Saito et al. (2014) [63]. Their report confirmed the survival of pathogenic Leptospira sp. in seawater for $4 \mathrm{~d}$, showing the ability of soil-inhabiting leptospires to persist even after a storm surge, and thus, the likelihood of a leptospirosis outbreak during seawater inundation episodes brought about by natural disasters. Khairani-Bejo (2004) reported the short survival of an isolate identified as $L$. interrogans serovar Hardjo in a medium with 3.78 and $3.85 \%$ salt content and $\mathrm{pH}$ of 6.5 to 6.8 [63]. The novel Leptospira spp. strain Manara isolated from Southern Right Whale tolerated at least $5 \%$ seawater in medium for $48 \mathrm{~h}$ [29]. Likewise, the present study supports the survival of Leptospira spp. survival in seawater as the two isolates from stranded cetaceans were found to tolerate up to $10 \%$ seawater in media for $2 \mathrm{~d}$. Seawater-tolerant leptospires may gain entry in

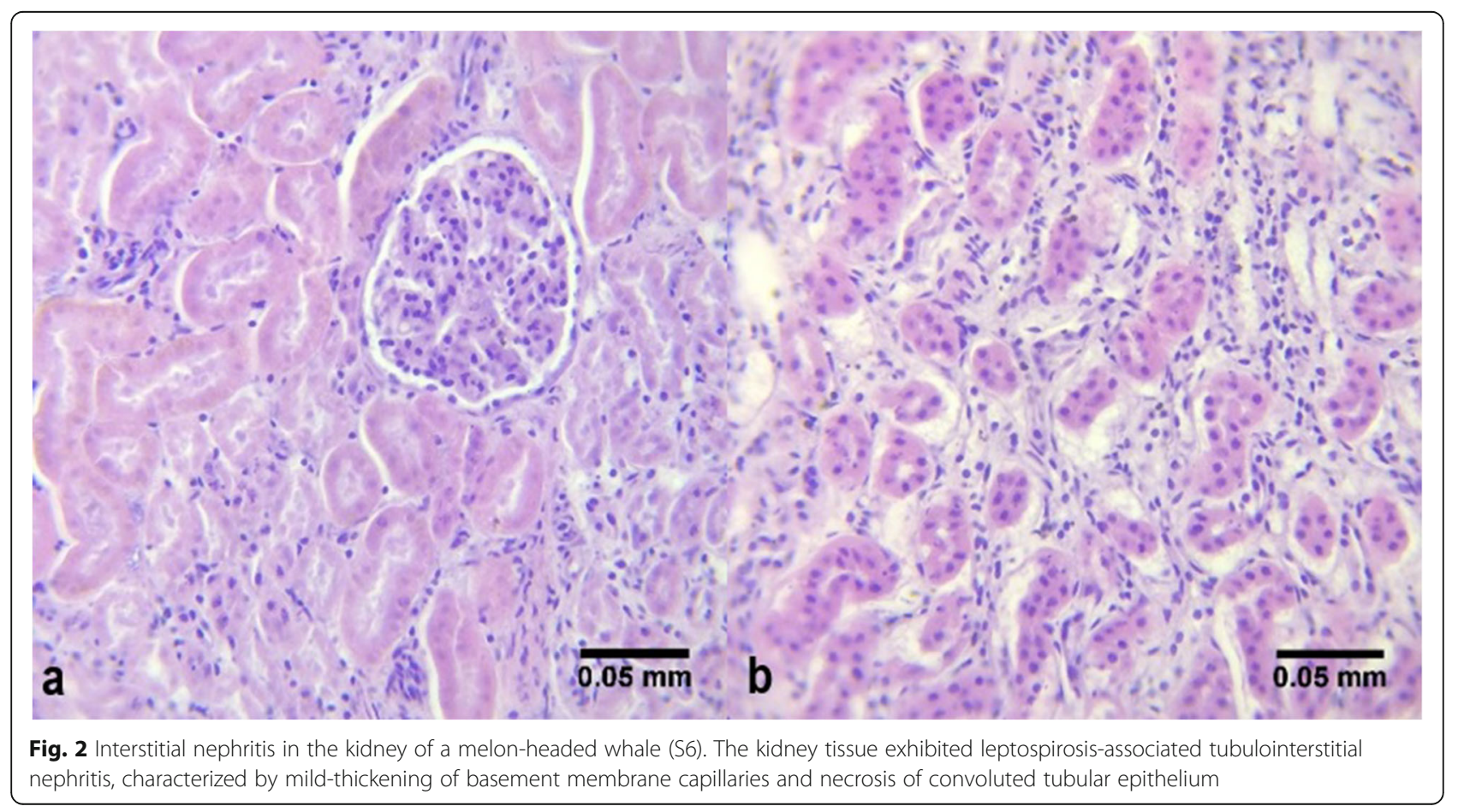




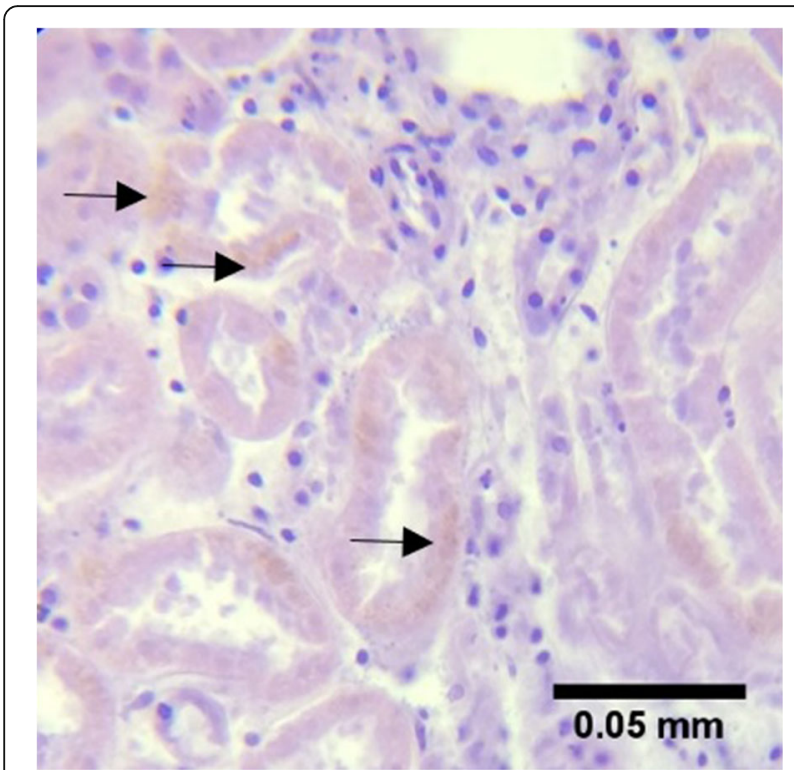

Fig. 3 Hemosiderosis: brown granular pigments (black arrows). Hemosiderosis was observed in the kidney tissue of a melon-headed whale (S6), characterized by the presence of hemosiderin pigments from hemoglobin degradation

cetaceans through direct contact with infected urine of infected or reservoir animals, or exposure to soil, water, and food that have been contaminated with infected urine. Among different hosts, transmissions through bites, tissue ingestion, sexual contact, breast milk, and placenta were also reported [63].

The known symptom of leptospirosis in marine mammals is interstitial nephritis, which is presented with clinical signs of impaired renal function including dehydration, polydipsia or excessive thirst, muscular tremors, abdominal pain, vomiting, and depression [24, 22]. The renal lesions in the melon-headed whale ( $P$. electra) were consistent with those associated with leptospirosis in California sea lions (Z. californianus) and Northern elephant seals ( $M$. angustirostris) that stranded along the coast of California [21-23]. The hemosiderosis observed in this particular cetacean, characterized by the presence of hemosiderin pigments from hemoglobin degradation, may result from infection, dietary deficiencies, excessive dietary iron (which increases susceptibility to bacterial infections and organ dysfunction), corticosteroids, and other toxins [63]. As bacterial infection can cause hemosiderosis, there is reason to suspect that this, together with tubulointerstitial nephritis, resulted from the infection of Leptospira sp. isolated from the kidney of the cetacean.

T. gondii in cetaceans found in the Philippines was first reported by Obusan et al. (2015) [51]. Since then, the protozoan parasite has been included as one of the target pathogens for the screening of cetaceans that strand in the country. As it is in the first study, the cetacean species where $T$. gondii was detected in this study were also pelagic such as the Risso's dolphin (G. griseus), Fraser's dolphin (L. hosei), spinner dolphin (S. longirostris), and others. This pose an interesting question as to how these cetaceans become exposed or infected with the parasite. The prevalence of toxoplasmosis in their populations is possible, given that $T$. gondii was detected in tissues of stranders through PCR and serological assays. However, the present interpretations are limited by the fact that only $T$. gondii specific IgG was detected, and that the presence of this type of antibody alone cannot unequivocally indicate a chronic infection. Recent reports suggest $T$. gondii specific IgM and/or IgG fail/s to differentiate between acute (3-6 months) and chronic (beyond 6 months) phases of toxoplasmosis as they are detected in both phases (80). In the case of humans, it is suggested that diagnosis for toxoplasmosis must be interpreted based on a combination of serological and molecular detection methods. For example, an acute infection can be indicated by concurrent IgM and low IgG avidity or a chronic infection can be indicated by concurrent IgM and high IgG avidity or IgG and high IgG avidity [63]. In addition, the use of molecular detection such as gene-specific PCR is helpful for confirming disseminated infection due to the systemic nature of toxoplasmosis as well as propagation of infection through body fluids $[84 ; 81]$. There is one cetacean (S24) that was positive for both IgG in the serum and $R E$ gene in the blood and cardiac and skeletal muscles, indicating a disseminated infection. Another individual (S25) was $R E$-gene positive but sero-negative; in this case, there is the likelihood that IgM antibodies were present but were not detected given the limitations of testing kits [63]. The other 15 cetaceans that were positive in PCR might either have disseminated infection (i.e., positive detection in blood of cetacean stranders (S4, S10, S12, S16, S18, S22, S24, and S25), and in both blood and muscles of cetacean stranders (S1, S2, S3, S4, S5, S10, S11, S12, S13, S16, S18, S21, S22, S24, and S25) or latent infection (i.e., positive detection of tissue cysts only in muscles of cetacean stranders S1, S2, S3, S5, S11, S13, and S21). The other five sero-positive cetaceans (S15, S36, S37, S39, and S40) that are negative in PCR detection can be safely said to have been exposed to the parasite.

Infection by $T$. gondii can occur transplacentally, or through the ingestion of food or water contaminated by oocysts as well as consumption of tissue with the bradyzoite stage of the parasite [44]. It is interesting to note that dolphins drink very small amount of water [44] and cetaceans in general are known to consume cephalopods, shrimps, and fishes [63] poikilothermic preys that are not hosts to T. gondii. However, Massie et al. (2010) proved that northern anchovies (Engraulis mordax) and 
Pacific sardines (Sardinops sagax) serve as biotic vectors for T. gondii transmission in marine environment [63]. With the elimination of carnivory feeding as the possible source of $T$. gondii in cetaceans, it is likely that oocyst contamination of marine water and prey item is a risk factor for infection, thus supporting pollution of their habitat by land to sea movement of the parasite. Such contamination is said to be coming from effluents as well as ship runoff waters containing oocysts [8,37], which can survive in the environment for years (Black and Boothroyd, 2000). Di Guardo and Mazzariol (2013) asserted that direct oocyst contamination of seawater from land-based effluents may explain the infection of coastal species such as bottlenose dolphins, however, in the case of $T$. gondii detection in pelagic species, the possibility of an "open sea T. gondii life cycle" that is different from the known land and benthic protozoan cycles must be considered [63]. It is also possible that transmission of the parasite or infection happened during migration. For example, toxoplasmosis is known to affect striped dolphins (S. coeruleoalba) in the Mediterranean region [37]. A stranded striped dolphin was also one of the samples in this study, and T. gondii was amplified from its blood. Striped dolphins are widelydistributed worldwide; they are found in warm temperate and tropical waters of Atlantic, Indian and Pacific Ocean [63]. Cetaceans are known to migrate, but information is lacking regarding the migration patterns and abundance ranges of many cetacean species in the Philippines.

Screening stranded cetaceans for the presence of target pathogens may help explain the possible cause/s of their stranding events and guide decisions in cases of medical intervention or rehabilitation. For example, the melon headed whale or P. electra (S6) may have stranded due to leptospirosis evidenced by tubulointerstitial nephritis with concurrent isolation of Leptospira sp. However, predation may have also contributed to the debility of the animal as shark bite was seen in its body. The dolphin was rehabilitated but died on 22 May 2017 (more information on this strander can be accessed through http://newsinfo.inquirer.net/895271/whale-nursed-backto-health-in-la-union) [63]. Another strander, the roughtoothed dolphin or S. bredanensis (S36) was found to be seropositive for T. gondii and Leptospira spp., confirming exposure to the pathogens. For its rehabilitation, the dolphin was first brought to a fish tank in BFARRMaTDeC (Regional Mariculture Technodermo Center) in Lucap Wharf, Alaminos, and then to the sea pen in Cariaz Island of Hundred Islands National Park, Pangasinan, Philippines. During the early days of rehabilitation, the animal showed symptoms of health problems which include diarrhea and expulsion of placental-like tissues indicative of either recent calf delivery or abortion prior to the stranding event. The dolphin was also observed to have abnormally short respiratory intervals, followed by straining and flexing, which could be an effort to expel placenta. Thus, antibiotics, pain relievers, oxytocin, dinoprost, and calcium were given to ease the symptoms and facilitate expulsion of any remaining placental tissues (L.J. Suarez, pers. comm., July 2018). While toxoplasmosis and leptospirosis are reported to cause abortion in animals [63], the limited serology cannot conclusively support such in the absence of corroborating findings due to limitations in the collected biological samples (e.g., available for PCR assay and histopathological analyses). The dolphin had IgG antibodies against $T$. gondi, which cannot differentiate between acute or chronic toxoplasmosis, and had IgM antibodies against Leptospira, which more likely indicate immune rather than acute phase of leptospirosis. As time progressed, continuous improvement in the dolphin's health and physical condition was observed until it was successfully released back into the wild on 21 August 2018 at Lingayen Gulf (news story on this strander can be accessed through http://www.pna.gov. $\mathrm{ph} /$ articles/1045798) [63]. Considering the foregoing cases, active infections cannot be confirmed in the absence of supporting pathological observations and detection tests.

\section{Conclusions}

Leptospira spp. and T. gondii were detected in cetaceans that stranded in the Philippines from October 2016-August 2018. This confirmed the plausibility of leptospirosis and toxoplasmosis in their populations, and the possible role of these infections in their local stranding events. Further studies should explore the specific mechanisms by which pelagic cetacean species become infected by Leptospira spp. and T. gondii, as well as the routes of transmission of these microorganisms in the marine environment. As there is growing evidence on the role of cetaceans as sentinels of landsea movement of emerging pathogens and the diseases they cause, any opportunity, such as their stranding events, should be maximized to investigate the health of their populations through their stranded representatives. Moreover, experiences in sampling and rehabilitating stranded cetaceans should guide future practices to prevent zoonotic transmissions at the humananimal interface.

\section{Methods}

\section{Stranded cetaceans}

Cetacean stranding events that occurred in the Philippines from October 2016-August 2018 were monitored and responded through collaboration with Philippine Marine Mammal Stranding Network (PMMSN) as 
well as Department of Agriculture's Bureau of Fisheries and Aquatic Resources (DA-BFAR). PMMSN has 12 regional and 32 provincial chapters that have marine mammal stranding response teams mandated by BFAR regional offices. The members and volunteers of the teams report any stranding event and the communication is coursed through channels until the information is relayed to the research team. Whenever logistically possible, stranding sites were reached by the researchers through land, air, or water travel. In cases wherein the stranding site was very remote and could not be reached immediately, biological material collection proceeded in coordination with PMMSN members who trained on medical aspects of marine mammal stranding response. All provincial chapters of DA-BFAR in different administrative regions have at least one veterinarian who completed such an intensive training course.

Stranded cetacean individuals were characterized in terms of: (1) species; (2) sex (based on genital and/or mammary slits); (3) age class (inferred from length relative to the species); (4) disposition (dead or alive); (5) stranding type (single or mass); (6) stranding site; and (7) stranding season (based on the scheme provided by Wang, 2006) [55]. Biological material collection was done based on the Code system established by the Smithsonian Institution's Marine Mammal Events Program [56]: Code 1- live animal; Code 2 - fresh (carcass in good condition); Code 3- fair (decomposed, but organs basically intact); Code 4- poor (advanced decomposition); and Code 5 - mummified or skeletal remains.

\section{Biological materials}

Blood was extracted either from the fluke vasculature (Code 1 specimen) or vena cava (Code 2 specimen). For serum recovery, whole blood was placed in serum separator tubes or kept warm until clotted for $30 \mathrm{~min}$ and centrifuged at $280 \mathrm{x}$ g for $7 \mathrm{~min}$. Sera were stored at $4{ }^{\circ} \mathrm{C}$ $-8{ }^{\circ} \mathrm{C}$ and processed within $48 \mathrm{~h}$ or stored in a $-80^{\circ} \mathrm{C}$ freezer for further analysis. Tissue samples $\left(<1 \mathrm{~cm}^{3}\right.$ each) from kidney (Codes 2-4 specimens), brain (Code 2 specimen only), heart, and skeletal muscles (Codes $2-$ 3 specimens) were obtained by performing necropsy. Urine samples $(\leq 3 \mathrm{~mL})$ were collected from Codes $1-3$ specimens. Following necropsy procedure, urine was aspirated from the exposed bladder with a syringe or squeezed through the penis of male individuals [57]. All biological samples were placed in sterile plastic bags, stored at $4{ }^{\circ} \mathrm{C}$ while on field work, and transferred immediately (preferably $<12 \mathrm{~h}$ ) to $\mathrm{a}-80^{\circ} \mathrm{C}$ freezer for analyses within 6 months.

\section{Serological assays}

Antibodies against Leptospira spp. were detected using enzyme-linked immunosorbent assay (SERION ELISA classic Leptospira IgM (Institut Virion\Serion $\mathrm{GmbH}$, Warburg, Germany) following manufacturer's instructions. IgM-ELISA used antigens from $L$. biflexa serovar Patoc strain Patoc I that contains genus specific epitopes for all Leptospira serovars. The test was developed to detect the complexes formed by human IgM and Leptospira antigens bound with goat antihuman IgM. The use of this test for non-human hosts relies on cross-reactivity of the goat antihuman IgM with IgM from other mammals. On the other hand, detection of IgG antibodies against T. gondii was done using Toxocell Latex Agglutination Test (LAT: BIOKIT Manufacturing Company, Barcelona, Spain), again, following manufacturer's instructions. The test used a suspension of polystyrene latex particles of uniform size coated with soluble $T$. gondii antigen.

\section{Leptospira culture}

Leptospira spp. were isolated from blood, urine, and kidney samples using Ellinghausen-McCullough-JohnsonHarris medium (EMJH) following the procedure of Loffler et al. (2015) [29]. Cultures were incubated at $28-30^{\circ} \mathrm{C}$ for a maximum of 3 months with dark-field microscopy examination every $15 \mathrm{~d}$ to check for turbidity and dinger ring formation as well as characteristic motility of Leptospira. Subcultures were prepared in case of positive Leptospira spp. growth with simultaneous testing of bacterial survival in halophilic condition through the addition of different seawater concentrations $(1,3,5,7$ and $10 \%, \mathrm{v} / \mathrm{v})$ [29].

\section{Histopathological examination}

Kidney tissues were placed in 10\% neutral-buffered formalin (with a tissue to fixative ratio of $1: 10$ ), embedded in paraffin, and sectioned at $5 \mu \mathrm{m}$ using a microtome. The tissue sections were then mounted on a slide, and subjected to hematoxylin and eosin staining [58]. Tissue lesions associated with leptospirosis were observed through microscopy.

\section{Molecular analyses}

Extraction of DNA from urine, kidney, blood, brain, and muscle samples proceeded using a commercially available kit (Promega, A1120: Wizard Genomic DNA Purification Kit). Extracted DNA samples were quantified using a spectrophotometer and then polymerase chain reaction (PCR) analyses were performed.

Pathogenic and non-pathogenic Leptospira spp. were targeted through nested PCR that amplified 525-bp (first round) and 289-bp (second round) fragments of the $16 \mathrm{~S}$ rRNA gene [50]. For first amplification, the primers used were: 5'-GGCGGCGCGTCTTAAACATG-3' and 5'GTCCGCCTACGCACCCTTTACG-3' while for second amplification, the primers were 5' CAAGTCA AGCGG AGTAGCAA-3' and 5' -CTTAACCTGCTGCCTCCCG 
TA-3' [59]. For both amplifications, the thermocycler conditions used were: $94^{\circ} \mathrm{C}$ for $5 \mathrm{~min}, 30$ cycles of $60^{\circ} \mathrm{C}$ for $2 \mathrm{~min}, 72^{\circ} \mathrm{C}$ for $1.5 \mathrm{~min}$, and $94^{\circ} \mathrm{C}$ for $1 \mathrm{~min}$, followed by $60^{\circ} \mathrm{C}$ for $2 \mathrm{~min}$ and $72^{\circ} \mathrm{C}$ for $15 \mathrm{~min}$ [59].

The $164 \mathrm{bp}$ region within the $529 \mathrm{bp}$ of the $T$. gondii $\mathrm{RE}$ gene was targeted by nested amplifications using primer pairs (1) 5'-TGACTCGGGCCCAGCTGCGT-3' and 5'CTCCTCCCTTCGTCCAAGCCTCC-3'; and (2) 5' -AGG GACAGAAGTCGAAGGGG-3' and 5'-GCAGCCAAGC CGGAAACATC-3' [60]. The thermocycler conditions used were: (1) for first amplification, $94^{\circ} \mathrm{C}$ for $5 \mathrm{~min}, 30$ cycles of $94{ }^{\circ} \mathrm{C}$ for $20 \mathrm{~s}, 55^{\circ} \mathrm{C}$ for $20 \mathrm{~s}, 72{ }^{\circ} \mathrm{C}$ for $20 \mathrm{~s}$ and $72{ }^{\circ} \mathrm{C}$ at $5 \mathrm{~min}$ final extension; and (2) for second amplification, $94^{\circ} \mathrm{C}$ for $5 \mathrm{~min}, 35$ cycles of $94{ }^{\circ} \mathrm{C}$ for $20 \mathrm{~s}, 55^{\circ} \mathrm{C}$ for $20 \mathrm{~s}, 72^{\circ} \mathrm{C}$ for $20 \mathrm{~s}$, and $72^{\circ} \mathrm{C}$ at $5 \mathrm{~min}$ final extension [61].

Reactions were performed in $25 \mu \mathrm{l}$ volume with the following concentrations of components: $1 \mathrm{X}$ PCR Master Mix (Vivantis: contains Taq DNA Polymerase, dNTPs, $\mathrm{MgCl} 2), 1.0 \mu \mathrm{M}$ assigned primers, $1.5-3.0 \mu \mathrm{L}$ DNA template, and nuclease-free water adjusted accordingly. Negative controls excluded DNA template. Positive controls included either DNA from $T$. gondii (Su, The University of Tennessee, Knoxville) or reference clinical strain of $L$. interrogans (Rivera, University of the Philippines, Diliman). Electrophoresis of PCR products in TAE (Tris-acetateEDTA) buffer was performed on agarose gels ( $2 \%$ for $16 \mathrm{~S}$ rRNA and $1.5 \%$ for $f l a B$ gene) at $8 \mathrm{~V} / \mathrm{cm}$ with DNA ladder (Vivantis, 100 bp Plus DNA ladder). Following electrophoresis, the gels were stained using GelRed and viewed through UV light exposure. PCR-positive samples were processed for purification, DNA quantification, and sequencing.

\begin{abstract}
Abbreviations
BFAR-RMaTDeC: Bureau of Fisheries and Aquatic Resources - Regional Mariculture Technodermo Center); bp: base pair; DA-BFAR: Department of Agriculture's Bureau of Fisheries and Aquatic Resources: dNTPs: deoxyribonucleotide triphosphate; ELISA: enzyme-linked immunosorbent assay; EMJH: Ellinghausen, McCullough, Johnson and Harris; flaB: flagellin B; IgG: immunoglobulin G; IgM: immunoglobulin M; LAT: Latex Agglutination Test; MAT: Microscopic Agglutination Test; $\mathrm{MgCl}_{2}$ : magnesium chloride; NCBI: National Center for Biotechnology Information; NE: northeast; PCR: Polymerase Chain Reaction; PMMSN: Philippine Marine Mammal Stranding Network; rDNA: ribosomal DNA; rRNA: ribosomal RNA;

SW: southwest; TAE: Tris-acetate-EDTA; Taq: Thermus aquaticus; UV: Ultraviolet
\end{abstract}

\section{Acknowledgements}

The authors thank Dr. Joseph S. Masangkay (College of Veterinary Medicine, University of the Philippines Los Ba os) for the shared expertise in histopathology, Dr. Leo Jonathan Suarez (Ocean Adventure, Subic) and Dr. Sandy Ling Choo (College of Veterinary Medicine, University of the Philippines Los Ba os) for the veterinary expertise; Dr. Chunlei Su (Department of Microbiology, University of Tennessee Knoxville) for T. gondii DNA samples; Darahlyn B. Romualdo (Institute of Environmental Science and Meteorology (IESM), UP Diliman), Jamaica Ann A. Caras (IESM, UP Diliman), Erika Joyce S. Calderon (Institute of Biology, UP Diliman), and Honey Leen M. Lagui (IESM, UP Diliman) for the technical assistance; and PMMSN members as well as DA-BFAR officers and veterinarians for the nationwide stranding response.

\section{Authors' contributions}

MCMO, MATS, WLR, and LVA conceived and designed the methodology. LVA led the cetacean stranding response and rehabilitation. MCMO, RMDV, MATS, and WLR performed the microbiological protocols. MCMO, RMDV and LVA performed sampling protocols. MCMO, RMDV, MATS, WLR, and LVA prepared the manuscript. All authors have read and approved the final version of the manuscript.

\section{Funding}

This study was funded by the Natural Sciences Research Institute (Project No. BIO-17-1-02) and Office of the Vice Chancellor for Research and Development (Project No. 171714 PhDIA), University of the Philippines Diliman. The funding agencies facilitated the release of funds and supervised the procurement of research materials and equipment, but were not involved in the study design, sample collection, data gathering and analysis, and manuscript writing.

\section{Availability of data and materials}

All data generated or analyzed are included in the article. Other relevant data may be requested through the corresponding author.

\section{Ethics approval and consent to participate}

The collection of biological specimens and information during cetacean stranding events was done in collaboration with a non-governmental organization, the Philippine Marine Mammal Stranding Network (PMMSN), and a government agency, the Department of Agriculture-Bureau of Fisheries and Aquatic Resources (DA-BFAR), which has the jurisdiction over cetacean species in the Philippines by virtue of Republic Act (RA) 8550 (amended as RA 10654). An active Memorandum of Agreement (MOA) that exists between these two organizations covers the response and sample collection protocols during marine mammal stranding events nationwide. The proposal for study was evaluated by the Research Committee of the Institute of Biology prior to submission to funding agencies. The study is exempted for clearance from the Institutional Animal Care and Use Committee (IACUC) of the University of the Philippines Diliman since cetaceans were not handled or maintained inside the premises

of the university.

\section{Consent for publication}

Not applicable.

\section{Competing interests}

The authors declare that they have no competing interests.

\section{Author details}

${ }^{1}$ Institute of Biology, College of Science, University of the Philippines, Diliman, Quezon City 1101, Philippines. ${ }^{2}$ Natural Sciences Research Institute, College of Science, University of the Philippines, Diliman, Quezon City 1101, Philippines. ${ }^{3}$ Institute of Environmental Science and Meteorology, College of Science, University of the Philippines, Diliman, Quezon City 1101, Philippines.

Received: 27 September 2018 Accepted: 24 September 2019

Published online: 26 October 2019

\section{References}

1. Aragones LV, Roque MA, Flores MB, Encomienda RP, Laule GE, Espinos BG, Maniago FE, Diaz GC, Alesna EB, Braun RC. The Philippine marine mammal strandings from 1998 to 2009: animals in the Philippines in peril? Aquat Mamm. 2010;36:219-33.

2. Aragones LV. Overview of Philippines marine mammals. In Marine mammal stranding response manual. $2^{\text {nd }}$ edition. Edited by Aragones LV, Lauie GE. Wildlife in Need (WIN) and Ocean Adventure. Subic Bay, Freeport; 2013. 6-30.

3. Bossart GD. Case study: marine mammals as sentinel species for oceans and human health. Oceanography. 2006;19:44-7.

4. Bossart GD. Marine mammals as sentinel species for oceans and human health. Vet Pathol. 2011;48:676-90.

5. Stewart JR, Gast RJ, Fujioka RS, Solo-Gabriele HM, Meschke JS, Amaral-Zettler LA, Holland AF. In Proceedings of the coastal environment and human health: Microbial indicators, pathogens, sentinels and reservoirs: 24-27 April 2007; Woodshole: Environmental Health 2008; 7:1-14. 
6. Duignan PJ. Disease investigations in stranded marine mammals, 1999-2002 (DOC science internal series 104), Wellington, NZ: Department of Conservation; 2003.

7. Alekseev AY, Reguzova AY, Rozanova El, Abramov AV, Tumanov YV, Kuvshinova IN, Shestopalov AM. Detection of specific antibodies to morbilliviruses, Brucella and Toxoplasma in the Black Sea dolphin Tursiops truncatus ponticus and the beluga whale Delphinapterus leucas from the Sea of Okhotsk in 2002-2007. Russ J Mar Biol. 2009;35:494-7.

8. Van Bressem MF, Raga JA, Di Guardo G, Jepson PD, Duignan PJ, Siebert U, Barrett T, Santos MC, Moreno IB, Siciliano S, Aguilar A, Van Waerebeek K. Emerging infectious diseases in cetaceans worldwide and the possible role of environmental stressors. Dis Aquat Org. 2009;86:143-57.

9. Brownstein D, Miller MA, Oates SC, Byrne BA, Jang S, Murray MJ, Gill VA, Jessup DA. Antimicrobial susceptibility of bacterial isolates from sea otters (Enhydra lutris). J Wildl Dis. 2011;47:278-92.

10. Moore SE. Marine mammals as ecosystem sentinels. J Mammal. 2008;89: 534-40

11. Pappas G, Papadimitriou P, Siozopoulou V, Christou L, Akritidis N. The globalization of leptospirosis: worldwide incidence trends. Int J Infect Dis. 2008; $12: 351-7$

12. Sterling $C R$, Thiermann AB. Urban rats as chronic carriers of leptospirosis: an ultrastructural investigation. Vet Pathol. 1981;18:628-37.

13. Guernier V, Goarant C, Banschop J, Lau CL. A systematic review of human and animal leptospirosis in the Pacific Islands reveals pathogen and reservoir diversity. PLoS Negl Trop Dis. 2018;12:1-32.

14. Chadsuthi S, Bicout DJ, Wiratsudakul A, Suwancharoen D, Petkanchanapong W, Modchang C, Triampo W, Ratanakom P, Chalvet-Monfray K. Investigation on predominant Leptospira serovars and its distribution in humans and livestock in Thailand, 2010-2015. PLoS Negl Trop Dis. 2017;11:1-18.

15. Jimenez-Coello M, Ortega-Pacheco A, Guzman-Marin E, Guiris-Andrade DM, Martinez-Figueroa L, Acosta-Viana KY. (2010). Stray dogs as reservoirs of the zoonotic agents Leptospira interrogans, Trypanosoma cruzi, and Aspergillus spp. in an urban area of Chiapas in Souther Mexico. Vector-Borne and Zoonotic Diseases, 2010; 10:135-141.

16. Lindtner-Knific R, Vergles-Rataj A, Vlahovic K, Zrimsek P, Dovc A. Prevalence of antibodies against Leptospira sp. in snakes, lizards and turtles in Slovenia. Acta Vet Scand. 2013;55:1-8.

17. Zuerner RL, Cameron CE, Raverty S, Robinson J, Colegrove KM, Norman SA, Lambourn D, Jeffries S, Alt DP, Gulland F. Geographical dissemination of Leptospira interrogans serovar Pomona during seasonal migration of California Sea lions. Vet Microbiol. 2009;137:105-10.

18. Delgado PM, Perea NS, Garcia CB, Davila CRG. Detection of infection with Leptospira spp. in manatees (Trichechus inunguis) of the Peruvian Amazon. Lat Am J Aquat Mamm. 2015;10:58-61.

19. Stamper MA, Gulland FMD, Spraker T. Leptospirosis in rehabilitated Pacific Harbor seals from California. J Wildl Dis. 1998:34:407-10.

20. Greig DJ, Gulland FM, Smith WA, Conrad PA, Field CL, Fleetwood M, et al. Surveillance for zoonotic and selected pathogens in harbor seals Phoca vitulina from Central California. Dis Aquat Org. 2014;111:93-106.

21. Colegrove KM, Lowenstine JL, Gulland FMD. Leptospirosis in northern elephant seals (Mirounga angustirostris) stranded along the California coast. J Wildl Dis. 2005;41:426-30

22. Gulland FMD, Koski M, Lowenstine $L$, Colagross A, Morgan L, Spraker T. Leptospirosis in California Sea lions (Zalophus californianus) stranded along the Central California coast, 1981-1994. J Wildl Dis. 1996:32:572.580.

23. Colagross-Schouten AM, Mazet JA, Gulland FM, Miller MA, Hietala S. Diagnosis and seroprevalence of leptospirosis in California Sea lions from coastal California. J Wildl Dis. 2002;38:7-17.

24. Cameron CE, Zuerner RL, Raverty S, Colegrove KM, Norman SA, Lambourn DM, Jeffries SJ, Gulland FM. Detection of pathogenic Leptospira bacteria in pinniped populations via PCR and identification of a source of transmission for zoonotic leptospirosis in the marine environment. J Clin Microbiol. 2008; 46:1728-33.

25. Acevedo-Whitehouse K, de la Cueva H, Gulland FM, Aurioles-Gamboa D, Arellano-Carbajal F, Suarez-Güemes F. Evidence of Leptospira interrogans infection in California Sea lion pups from the Gulf of California. J Wildl Dis. 2013;39:145-51.

26. Prager KC, Greig DJ, Alt DP, Galloway RL, Hornsby RL, Palmer LJ, Soper J, Wu Q, Zuerner RL, Gulland FMD, Lloyd-Smith JO. Asymptomatic and chronic carriage of Leptospira interrogans serovar Pomona in California Sea lions (Zalophus californianus). Vet Microbiol. 2013;164:178-83.
27. Sepulveda MA, Seguel M, Alvarado-Rybak M, Verdugo C, Muñoz-Zanzi C, Tamayo R. Postmortem findings in four south American sea lions (Otaria byronia) from an urban colony in Valdivia, Chile. J Wildl Dis. 2015;51:279-82.

28. Namroodi S, Shirazi AS, Khaleghi SR, Mills JN, Kheirabady V. Frequency of exposure of endangered Caspian seals to canine distemper virus, Leptospira interrogans, and Toxoplasma gondii. PLoS One. 2018;13:1-10.

29. Loffler SG, Rago V, Martínez M, Uhart M, Florin-Christensen M, Romero G, Brihuega B. Isolation of a seawater tolerant Leptospira spp. from a southern right whale (Eubalaena australis). PLoS One. 2015;10:1-10.

30. Bik EM, Costello EK, Switzer AD, Callahan BJ, Holmes SP, Wells RS, Carlin KP, Jensen ED, Venn-Watson S, Relman DA. Marine mammals harbor unique microbiotas shaped by and yet distinct from the sea. Nat Commun. 2016;7:1-13.

31. Jones JL, Dubey JP. Waterborne toxoplasmosis - recent developments. Exp Parasitol. 2010;124:10-25.

32. Dubey JP. Toxoplasmosis - a waterborne zoonosis. Vet Parasitol. 2004; 126:57-72.

33. Bowie WR, King AS, Warker DH, Isaac-Renton JL, Bell A, Eng SB, Marion SA. Outbreak of toxoplasmosis associated with municipal drinking water. The BC toxoplasma investigation team. Lancet. 1997;350:173-7.

34. Mazzariol S, Marcer F, Mignone W, Serracca L, Goria M, Marsili L, Di Guardo G, Casalone C. Dolphin Morbillivirus and Toxoplasma gondii coinfection in a Mediterranean fin whale (Balaenoptera physalus). BMC Vet Res. 2012:8:1-5.

35. Forman D, West N, Francis J, Guy E. The sero-prevalence of Toxoplasma gondii in British marine mammals. Mem Inst Oswaldo Cruz. 2009;104: 296-8.

36. Gibson KA, Raverty S, Lambourn DM, Huggins J, Magargal SL, Grigg ME. Polyparasitism is associated with increased disease severity in Toxoplasma gondii-infected marine mammal sentinel species. PLoS Negl Trop Dis. 2011:5:1-13.

37. Di Guardo G, Proietto U, Di Francesco CE, Marsilio F, Zaccaroni A, Scaravelli D, Mignone W, Garibaldi F, Kennedy S, Forster F, Iulini B, Bozzetta E Casalone C. Cerebral toxoplasmosis in striped dolphins (Stenella coeruleoalba) stranded along the Ligurian Sea coast of Italy. Vet Pathol. 2010;47:1-32.

38. Migaki G, Sawa TR, Dubey JP. Fatal disseminated toxoplasmosis in a spinner dolphin (Stenella longirostris). Vet Parasitol. 1990;27:463-4.

39. Inskeep W, Gardiner CH, Harris RK, Dubey JP, Goldston RT. Toxoplasmosis in Atlantic bottle-nosed dolphins (Tursiops truncatus). J Wildl Dis. 1990; 26:377-82.

40. Omata Y, Hammond T, Itoh K, Murata K. Antibodies against Toxoplasma gondii in the Pacific bottlenose dolphin (Tursiops truncatus) from the Solomon Islands. J Parasitol. 2005;91:965-7.

41. Measures LN, Dubey JP, Labelle P, Martineau D. Seroprevalence of Toxoplasma gondii in Canadian Pinnipeds. J Wildl Dis. 2004;40:294-300.

42. Bigal E, Morick D, Scheinin AP, Salant H, Berkowitz A, King R, Levy Y, Melero M, Sanchez-Viscaino JM, Goffman O, Hadar N, Roditi-Elasar M, Tchernov D. Detection of Toxoplasma gondii in three common bottlenose dolphins (Tursiops truncatus); a first description from the eastern Mediterranean Sea. Vet Parasitol. 2018;258:74-8.

43. Pretti C, Mancianti F, Nardoni S, Ariti G, Monni G, Bello D, Marsili S, Papini R. Detection of Toxoplasma gondii infection in dolphins stranded along the Tuscan coast, Italy. Rev Med Vet. 2010;161:428-31.

44. Dubey JP, Zarnke R, Thomas NJ, Wong SK, Van Bonn W, Briggs M, Davis JW, Ewing R, Mense M, Kwok OCH, Romand S, Thulliez P. Toxoplasma gondii, Neospora caninum, Sarcocystis neurona, and Sarcocystis canis-like infections in marine mammals. Vet Parasitol. 2003;116:275-96.

45. Shapiro K, Miller MA, Packham AE, Aguilar B. Dual congenital transmission of Toxoplasma gondii and Sarcocystis neurona in a late-term aborted pup from a chronically infected southern sea otter (Enhydra lutris nereis). Parasitology. 2015;143:276-88.

46. Rengifo-Herrera C, Ortega-Mora LM, Alvarez-Garcia G, Gomez-Bautista M, Garcia-Parraga D, Garcia-Pena FJ, Pedraza-Diaz S. Detection of Toxoplasma gondii antibodies in Antarctic pinnipeds. Vet Parasitol. 2012; 10:259-62.

47. Dubey JP, Fair PA, Sundar N, Velmurugan G, Kwok OCH, McFee WE, Majumdar D, Su C. Isolation of Toxoplasma gondii from bottlenose dolphins (Tursiops truncatus). J Parasitol. 2008;94:821-3.

48. Gajadhar AA, Measures L, Forbes LB, Kapel C, Dubey JP. Experimental Toxoplasma gondii infection in Grey seal (Halichoerus grypus). J Parasitol. 2004;90:255-9. 
49. Conrad PA, Miller MA, Kreuder C, James ER, Mazet J, Dabritz H, Jessup DA, Gulland F, Grigg ME. Transmission of toxoplasma: clues from the study of sea otters as sentinels of Toxoplasma gondii flow into the marine environment. Int J Parasitol. 2005;35:1155-68.

50. Bossart GD, Mignucci-Giannonni AA, Rivera-Guzman AL, Jimenez-Marrero NM, Camus AC, Bonde RK, Dubey JP, Reif JS. Disseminated toxoplasmosis in Antillean manatees Trichechus manatus manatus from Puerto Rico. Dis Aquat Org. 2012;101:139-44.

51. Obusan MCM, Aragones LV, Salibay CC, Siringan MAT, Rivera WL. Occurrence of human pathogenic bacteria and Toxoplasma gondii in cetaceans stranded in the Philippines: providing clues on ocean health status. Aquat Mamm. 2015;41:149-66.

52. Aragones LV, Laggui HLM, Amor AKS. The Philippine Marine Mammal Strandings from 2005 to 2016. Quezon City, Philippines: A PMMSN Publication. Technical Report No. 1. 2017.

53. Bogomolni AL, Gast RJ, Ellis JC, Dennett M, Pugllares KR, Lentell BJ, Moore MJ. Victims or vectors: a survey of marine vertebrate zoonoses from coastal waters of the Northwest Atlantic. Inter-Research Diseases of Aquatic Organisms. 2008:81:13-38.

54. McFee WE, Lipscomb TP. Major pathologic findings and probable causes of mortality in bottlenose dolphins stranded in South Carolina from 1993 to 2006. J Wildl Dis. 2009;45:575-93.

55. Wang B. The Asian monsoon. Chichester, UK:Springer-Vertag. 2006

56. Geraci JR, Lounsbury VJ. Marine mammals ashore: a field guide for strandings. 2nd ed. College Station: Texas A\&M University Sea Grant College Program; 2005.

57. Backstedt BT, Buyuktanir O, Lindow J, Wunder EA Jr, Reis MG, Usmani-Brown S, Michel Ledizet M, Ko A, Utpal PU. Efficient detection of pathogenic leptospires using 16s ribosomal RNA. PLoS One. 2015;10:1-18.

58. Ross MH, Pawlina W. Histology, A text and Atlas. 6th ed. Baltimore: Williams, Wilkins \& Co. Chapter 16. 2011; p 550-551.

59. Djadid ND, Ganji ZF, Gouya MM, Rezvani M, Zakeri S. A simple and rapid nested polymerase chain reaction-restriction fragment length polymorphism technique for differentiation of pathogenic and nonpathogenic Leptospira spp. Diagn Microbiol Infect Dis. 2009;63:251-6.

60. Homan WL, Vercammen M, De Braekeleer J, Verschureren H. (1999). Identification of a 200- to 300- fold repetitive 529 bp DNA fragment in Toxoplasma gondii, and its use for diagnostic and quantitative PCR. Int J Parasitol 1999; 30:69-75.

61. Fallahi S, Kazemi B, Seyyed tabaei SJ, Bandehpour M, Lasjerdi Z, Taghipour N, Zebardast N, Nikmanesh B, Fallah Omrani V, Ebrahimzadeh F. Comparison of the RE and B1 gene for detection of Toxoplasma gondii infection in children with cancer. Parasitol Int. 2014;63:37-41.

62. Norman SA, DiGiacomo RF, Gulland FMD, Meschke JS, Lowry MS. Risk factors for an outbreak of leptospirosis in California Sea lions (Zalophus californianus) in California. 2004. J Wildl Dis. 2008;44:837-44

63. Saito M, Miyahara S, Villanueva SYAM, Aramaki N, Ikejiri M, Kobayashi Y, Guevarra JP, Masuzawa T, Gloriani NG, Yanagihara Y, Yoshida S. PCR and Culture Identification of Pathogenic Leptospira spp. from Coastal Soil in Leyte, Philippines, after a Storm Surge during Super Typhoon Haiyan (Yolanda). Appl Environ Microbiol. 2014;80:6926-32.

64. Khairani-Bejo S, Bahaman AR, Zamri-Saad M, Mutalib AR. The Survival of Leptospira interrogans serovar Hardjo in the Malaysian Environment. J Anim Vet Adv. 2004:3:123-9.

65. Sykes JE. Leptospirosis. In Canine and Feline Infectious Diseases; 1stEdition. St. Louis, Missouri: Elsevier Saunders; 2014. p. 474-86.

66. Forbes AE, Zochowski WJ, Dubrey SW, Sivaprakasam V. Leptospirosis and Weil's Disease in the UK. Q J Med. 2012:105:1151-62.

67. Pal M, Hadush A. Leptospirosis: An Infectious Emerging Waterborne Zoonosis of Global Significance. Air Water Borne Dis. 2017;6:1-4

68. Zuerner RL, Cameron CE, Raverty S, Robinson J, Colegrove KM, Norman SA, Lambourn D, Jeffries S, Alt DP, Gulland F. Geographical dissemination of Leptospira interrogans serovar Pomona during seasonal migration of California sea lions. Vet Microbiol. 2009:137:1-2.

69. Mitchell TM, Shinkareva SV, Carlson A, Chang KM, Malave VL, Mason RA, Just MA. Predicting human brain activity associated with the meanings of nouns. Science. 2008:320:5880:1191-5.

70. Esa HAH, Amran F, Halim AN. Evaluation of a Commercial Enzyme-Linked Immunosorbent Assay Kit for Detection of IgM Antibody against Leptospira in Human Sera for Patients admitted in Malaysian Hospitals. Clin Microbiol. 2018;7:1-4.
71. [https://www.bio-rad-antibodies.com/polyclonal/human-igm-antibodystar145.html?f=purified\#summary]. Accessed 2 May 2019.

72. Adler B, Faine S. The Antibodies Involved in the Human Immune Response to Leptospiral Infection. J Med Microbiol. 1978;11:387-400.

73. Kumar D, Cowan DF. Cross-Reactivity of Antibodies to Human Antigens with tissues of the Bottlenose Dolphin, using Immunoperoxidase techniques. Mar Mamm Sci. 1994;10:188-94.

74. Jaber JR, Fernandez A, Herraez P, Espinosa de los Monteros A, Ramirez GA, Garcia PM, Fernandez T, Arbelo M, Perez J. Cross-reactivity of human and bovine antibodies in striped dolphin paraffin wax-embedded tissues. Vet Immunol Immunopathol. 2003;96:65-72.

75. Nouri-Shirazi M, Bible BF, Zeng M, Tamjidi S, Bossart GD. Phenotyping and comparing the immune cell populations of free-ranging Atlantic bottlenose dolphins (Tursiops truncatus) and dolphins under human care. BMC Vet Res. 2017;13:1-14.

76. Dubey JP, Sundar N, Hill D, Velmurugan GV, Bandini LA, Kwok, OCH, Majumdar D, Su C. High Prevalence and abundant atypical genotypes of Toxoplasma gondii isolated from lambs destined for human consumption in the USA. Int J Parasitol. 2008;38:999-1006.

77. MacLeod CD, Santos MB, Pierce GJ. Review of data on diets of beaked whales; evidence of niche separation and geographic segregation. J Mar Biol Ass. 2003:83:651-65.

78. Bloodworth BE, Odell DK. Kogia breviceps (Cetacea:Kogiidae). Mammalian species. 2008:819:1-12.

79. Massie GN, Ware MW, Villegas EN, Black MW. Uptake and transmission of Toxoplasma gondii oocysts by migratory, filter-feeding fish. Vet Parasitol. 2010;169:3-4.

80. Di Guardo G, Mazzariol S. Toxoplasma gondii: Clues from Stranded Dolphins. Vet Pathol. 2013;50:737.

81. Van Waerebeek K, Felix F, Haase B, Palacios DM, Mora-Pinto DM,MunozHincapie M. Inshore Records of the Striped dolphin (Stenella coeruleoalba), from the Pacific Coast of South America. Rep Int Whal Comn. 1998;48:52532.

82. [http://newsinfo.inquirer.net/895271/whale-nursed-back-to-health-in-launion]. Accessed 26 Sept 2018.

83. Slee KJ, McOrist S, Skilbeck NW. Bovine abortion associated with Leptospira interrogans serovar hardjo infection. Aust Vet J. 1983:60:204-06.

84. Haake DA, Levett PN. Leptospirosis in Humans. Curr Top Microbiol 2015;387: 65-97.

85. Lizer J, Velineni S, Weber A, Krecic M, Meeus P. Evaluation of 3 Serological Tests for Early Detection of Leptospira-specific Antibodies in Experimentally Infected Dogs. J Vet Intern Med. 2018;32:201-7.

86. [http://www.pna.gov.ph/articles/1045798]. Accessed 23 Sept 2018.

\section{Publisher's Note}

Springer Nature remains neutral with regard to jurisdictional claims in published maps and institutional affiliations.

Ready to submit your research? Choose BMC and benefit from:

- fast, convenient online submission

- thorough peer review by experienced researchers in your field

- rapid publication on acceptance

- support for research data, including large and complex data types

- gold Open Access which fosters wider collaboration and increased citations

- maximum visibility for your research: over $100 \mathrm{M}$ website views per year

At BMC, research is always in progress.

Learn more biomedcentral.com/submissions 